3. Педагогічний репертуар вокаліста. Романси та обробки народних пісень українських композиторів-класиків. Баритон. Випуск 1 / Упоряд. Н. В. Татаринова. К.: Мистецтво, 1966. 56 с.

4. Стулова Л. Вопросы вокального воспитания актера драматического театра. М.: [б. и.], 1974. 99 с.

5. Хрестоматия вокально-педагогического репертуара для баритона и баса / сост. Г. Аден. М.: Музыка, 1966. 127 с.

DOI https://doi.org/10.30525/978-9934-26-004-9-24

\title{
ОБРАЗ-СИМВОЛ ЄВШАН-ЗІЛЛЯ У ПОЕЗІЇ Б. КРАВЦІВА
}

\author{
Жураківська О. О. \\ аспірант \\ Прикарпатського національного університету \\ імені Василя Стефаника \\ м. Івано-Франківськ, Украӥна, \\ учитель украӥнської мови та літератури \\ Калуського лічею імені Дмитра Бахматюка \\ м. Калуш, Івано-Франківська область, Украӥна
}

Мистецька доля Б. Кравціва, українського письменника-емігранта, щедра на талант, випрозорена печаллю, наділена духовними вимірами. Храм свого духу поет закладав, мурував і вимурував на фундаменті найшляхетніших українських та світових надбань. У цю фортецю увійшла й гідна схиляння та подиву культура страждання. У його поезіях - згусток доль, сакральність євшан-зілля, неминучість кінця, вічність початку, важке самоствердження людини.

В еміграційний період у Свропі Б. Кравців видав такі поетичні збірки: «Остання осінь» (Прага, 1940; Берлін, 1941), «Під чужими зорями» (Берлін, 1941), «Кораблі: Вибрані поезії» (1922-1947 (Байрот), 1948).

Варто зазначити, що саме збірка «Остання осінь» символізувала завершення цілої довоєнної епохи, пов'язаної з рідною землею. У поезії Б. Кравціва звучить ностальгійна нота переживання емігранта, відчуття непоправних втрат, глибокі роздуми над причинами й сутністю Голгофи України. Всесвітня печаль пронизує твори поета про невідворотність того, що записано в книгу життя. Зв'язок із рідною землею втілився в україноцентичній поезії Кравцева. Науковець О. Гордійчук зазначає: «Архетип Землі - у своїй основі містить споконвічно високий рівень 
довіри до «доброї неньки землі», має суттєвий вплив на формування психологічного оптимізму та гармонійного світовідчуття українського народу завдяки щедрим природним умовам [2, с. 17].

Домінуючий образ-символ у творчості митця - євшан-зілля, наповнений трагічним світовідчуттям втраченої Вітчизни. Відомо, що євшан-зілля - це символ пам'яті рідної землі, Батьківщини. Свшан-зілля (полин) - степова запашна рослина із червоним або пурпуровим цвітом. Слово «євшан» за походженням тюркське. В українському фольклорі полин - надійний оберіг від русалок, іншої нечисті. Образ «євшан-зілля» став літературною традицією. Він зустрічається у творах І. Франка, М. Вороного, Л. Забашти, М. Чабанівського, В. Коломійця та ін.

Особливо промовиста назва збірки Б. Кравціва «Під зорями чужими». У ній невимовний біль за втраченим, а рідна земля розкривається в семантичному полі через «національно-історіософські модуси «Роду й Дому», які для поета $є$ сакральними» [1, с. 94].

Під світом зір чужих - в годину пізню самотніх ночей - раптом так збагнем, впечемо серце жаром наглим врізу:

- Даремне все! Від себе не втечем! -

Тож дум шалених не змогти залізу ні мрій, ні вольних поривів мечем! -

Як з серця їдь не витравить зміїна

семи тих літер - слова: Україна! [3, с. 126]

Науковець Т. Салига глибоко аналізує емігрантський період Б. Кравціва: «Особисто пережите на теренах літературної і наукової творчості, громадської і політичної діяльності, болісні роздуми про минуле і майбутнє рідної Батьківщини, що вабить-кличе із чужини синів своїх незабутнім запахом євшану - все це відлунює у творчості поета перших літ вимушеної еміграції» [5, с. 15].

Символом почуттів і думок вигнанця $є$ журавель, який завжди вертається до рідного краю:

Блищать поля важким сріблом землі

і золотіє ліс осіннім листом:

далеко в хмарах кличуть журавлі

за ясним сонцем в далечінь одплисти.

****

В незнану далечінь, де буйні дні

пливуть ударами їх крил невтомних,

горять на грудях відблиски вогнів

і кличуть світ їх криком невгомонним [3, с. 35]. 
Вважається, що журавель є символом духовності та атрибутом Батьківщини. У художньому просторі митців цей образ $є$ архетипом. У міфології багатьох народів птахи $є$ творцями Всесвіту. Простежується чіткий поділ птахів на «чистих (божих)» та «нечистих». До перших відносяться лелека, журавель. Отже, це святий птах. Вважається, що він приносить добро, щастя, весну. I найголовніше, цей птах сприймається як національна константа гармонії. У поезії Б. Кравціва «Журавлі» відкриваються нові семантичні площини. Митець подає власну інтерпретацію: журавлі - це сміливий, лицарський образ юних патріотів, у яких «горять на грудях відблиски вогнів» [3, с. 35], бо справжні герої готові нести великі ідеї у майбутнє. Саме це індивідуальне авторське змістове наповнення надає поезії оптимістичного вістря. Поетичне слово Б. Кравціва у творі «Журавлі» увиразнюється через метафоричне згущення амбівалентної образності вогню.

Справді, тема тривожної одіссеї чужими землями з мріями-ілюзіями про повернення $\epsilon$ домінантою у творчості багатьох письменниківемігрантів. Тому у вступній статті до антології «Координати» I. Фізер наголошує, що «втрачена батьківщина і майже травматична туга за нею в творчості поетів-емігрантів є фактором великого значення. Вона частогусто мобілізує їхню увагу, вона викликає надмірну ідеалізацію історичної минувшини» [6, с. 24].

Варто зазначити, що втрата рідної землі переростає у творчості Б. Кравціва в авторський концепт, наповнений екзистенційно драматичним і трагічним світовідчуттям. Значущим у цьому сенсі $\epsilon$ вибраний епіграф Юрія Клена до збірки поета «Під зорями чужими»:

А про красу заквітчаних долин, Про любі серцю комиші і хащі, Про те, як пахне на межі полин, I про вигнанця долю злу й пропащу, Який не бачить рідних луговин, -

За мене ще майстерніше і краще

Вам оповів би половецький хан,

Якому хтось дав нюхати євшан [4, с. 67]

Найбільш вагомий i потужний, до щему рідний i глибинний, з'являється образ-символ євшан-зілля у вінку сонетів «Дзвенислава». Витончені словесні обертони, інкрустовані батьківські теплота й любов струменять у поетичних рядках:

Із чару слова, з горстки євшан-зілля,

Із крихти запашної зелен-рути,

Що збереглися скарбом призабутим

Крізь дні тривоги, злоби й божевілля *** 
В клунках вигнанців з рідного привілля,

Де цвіти пахнуть п'яно, де натхнуті

І тугою, й коханням людські путі,

Де хліб запікся щирим сонцем й сіллю,

***

Сьогодні вичаровую рядки ці,

Мелодії пісень і гомін дзвонів,

Що ними серце сповнене до краю [3, с. 140-141].

Воістину правдиві слова: які б випробування не готувала доля людині, а нитка поколінь живе, бо тримає ії терпкий трунок євшан-зілля i не дає забути запах рідної землі.

\section{Література:}

1. Василишин I. П. Антеїстичні концепти в ліриці Богдана Кравціва (дискурс чужини). Закарпатські філологічні студії. Вип. 13. Т. 3. С. 91-96. (https://doi.org/10.32782/TPS2663-4880/2020.13-3.16).

2. Гордійчук О. О. Архетипи української ментальності: соціальнофілософський аналіз. Філософські науки. Вип. 1 (84). С. 15-19.

3. Кравців Б. Зібрані твори. Нью-Йорк : Вид-во Нью-Йоркської групи. 1978. Т. $1.380 \mathrm{c.}$

4. Кравців Б. Під рідними і зорями чужими / упоряд. Т. Салига, I. Василишин. Львів : Світ, 2018. 648 с.

5. Салига Т. «...3-під «зір чужих» у «дні колишні»... (Богдан Кравців)». Богдан Кравців. Під рідними і зорями чужими / упоряд. Т. Салига, І. Василишин. Львів : Світ, 2018. 648 с. С. 3-23.

6. Фізер I. Вступна стаття. Координати. Антологія сучасної української поезії на Заході : у 2 т. / упоряд. Богдан Бойчук і Богдан Рубчак. Т. 1. Нью-Йорк : Сучасність, 1969. С. 13-32. 